\title{
Problem solving skills: essential skills challenges for the 21st century graduates
}

\author{
Khairul Bariyyah ${ }^{1}$ \\ ${ }^{1}$ Universitas PGRI Kanjuruhan Malang, Indonesia
}

\begin{tabular}{l} 
Article Info \\
\hline Article history: \\
Received Jun $15^{\text {th }}, 2021$ \\
Revised Jul $23^{\text {th }}, 2021$ \\
Accepted Aug $29^{\text {th }}, 2021$ \\
\hline
\end{tabular}

\section{Keyword:}

Problem solving skill

Gender

Developmental stages

Age

\begin{abstract}
Problem solving skills are the abilities to identify problems, search and select various alternative solutions and make decisions in solving all the problems at hand. Problem solving skills are 21 st century skills that are needed by society and the world of work. This research is a descriptive quantitative research. The research sample consisted of 300 students who were selected using the stratified random sampling technique. The research instrument used a scale of student problem solving skills. The Analysis of Data used descriptive analysis, independent sample t-test, and ANOVA with the help of the SPSS program. Based on the results of the study, it can be concluded (1) the average level of student problem solving skills is in the medium category $(62.3 \%),(2)$ there is no significant difference in the level of student problem solving skills based on gender, (3) there is no significant difference in the level of student problem solving skills based on developmental status, (4) there is a significant difference in the level of problem solving skills of students based on age groups. The age group that has a significant effect on the difference in the average score of problem solving skills of students aged 23 years.
\end{abstract}

(C) 2021 The Authors. Published by IICET

This is an open access article under the CC BY-NC-SA license

(https://creativecommons.org/licenses/by-nc-sa/4.0

\section{Corresponding Author:}

Bariyyah, K.,

Universitas PGRI Kanjuruhan Malang, Indonesia

Email: khairulbariyyah@unikama.ac.id

\section{Introduction}

Selama dekade terakhir abad ke-20 dan memasuki abad ke-21, masyarakat telah mengalami percepatan perubahan ekonomi dan teknologi (Chalkiadaki, 2018). Hal ini juga berdampak pada dunia kerja dan menuntut sistem pendidikan dapat mempersiapkan siswa yang siap memenuhi tuntutan tempat kerja dan masyarakat. Hingga awal abad ke-21, sistem pendidikan di seluruh dunia difokuskan pada persiapan siswanya untuk menguasai berbagai pengetahuan (Cheng, 2017). Akibatnya, sekolah berfokus pada penyediaan keterampilan melek huruf dan berhitung kepada siswanya, karena keterampilan ini dianggap perlu untuk menguasai berbagai pengetahuan (Rios et al., 2020; Scoular \& Care, 2018). Perkembangan terkini dalam teknologi dan telekomunikasi telah membuat informasi dan pengetahuan ada di mana-mana dan dengan mudah dapat diakses di abad ke-21. Oleh karena itu, meskipun keterampilan seperti literasi dan berhitung masih relevan dan diperlukan, keterampilan tersebut tidak lagi memadai. Untuk menanggapi perubahan teknologi, demografi dan sosial-ekonomi, sistem pendidikan mulai melakukan pergeseran ke arah memberikan siswa mereka berbagai keterampilan yang tidak hanya mengandalkan kognisi tetapi juga pada saling ketergantungan karakteristik kognitif, sosial, dan emosional (Urbani et al., 2017; Meyer \& Norman, 2020); Johnson \& Acabchuk, 2018). 
Penyiapan sumber daya manusia yang menguasai keterampilan abad ke-21 akan efektif jika ditempuh melalui jalur pendidika (Mestry, 2017). Pada setting perguruan tinggi, Program Kurikulum Merdeka Belajar Kampus Merdeka (MB-KM) merupakan bagian dari upaya Kementerian Pendidikan dan Kebudayaan RI atas tuntutan link and match dengan Industri, dunia kerja, penelitian dan kebutuhan desa, kecamatan, kabupaten/ kota, provinsi, negara dan dunia (Arifin \& Muslim, 2020). Proses pembelajaran dalam Kampus Merdeka merupakan salah satu perwujudan pembelajaran yang berpusat pada mahasiswa (student centered learning) yang sangat esensial. Pembelajaran dalam Kampus Merdeka memberikan tantangan dan kesempatan untuk pengembangan kreativitas, kapasitas, kepribadian, dan kebutuhan mahasiswa.

Mahasiswa sering dikatakan sebagai kaum terdidik dan kaum intelektual yang keberadaannya diharapkan mampu menjadi pemimpin dan membawa perubahan bagi bangsa dan negara di masa yang akan datang. Sebagai kaum intelektual, mahasiswa diharapkan mampu berperilaku dan menunjukan kualitas intelektualnya terutama dalam memecahkan masalah yang dihadapi. Salah satu soft skill yang menggerakkan kemampuan intelektual para mahasiswa adalah problem solving skills. Oleh karena itu, problem solving skills merupakan salah satu indikator dari perilaku intelektual dan keterampilan berfikir tingkat tinggi yang perlu dikuasai oleh mahasiswa (Ichsan et al., 2019; Akben, 2020).

Problem solving skills merupakan kemampuan yang didasari dengan proses mengidentifikasi masalah, mencari solusi alternatif, dan menerapkan solusi terbaik dalam situasi yang relatif baru (Araiza-Alba et al., 2021; Graesser et al., 2018; Pinter \& Cisar, 2018). Sedangkan Özreçberoğ lu \& Çağ anağ a, (2018) menyatakan bahwa problem solving skills merupakan kemampuan untuk menyelesaikan segala masalah dan mengambil keputusan yang sulit. Dörner \& Funke, (2017) mendefinisikan problem solving skills sebagai kemampuan mendefinisikan masalah, menentukan penyebab masalah, menentukan prioritas, menyeleksi berbagai pilihan solusi dan mengimplementasikan solusi tersebut. Berdasarkan pendapat beberapa ahli tersebut dapat didefinisikan bahwa problem solving skills adalah kemampuan mengidentifikasi masalah, mencari dan menyeleksi berbagai solusi alternatif dan menentukan keputusan dalam menyelesaikan segala masalah yang dihadapi.

Problem solving skills tidak hanya dibutuhkan mahasiswa dalam kehidupan sehari-hari tetapi juga dibutuhkan di dunia kerja. National Research Council (USA) telah mengidentifkasi keterampilan abad ke-21 yang dibutuhkan masyarakat dan dunia kerja. Keterampilan tersebut dibagi menjadi tiga domain kompetensi: interpersonal, intrapersonal, dan kognitif (Araiza-Alba et al., 2021; Care et al., 2018; Rios et al., 2020; Kutlu \& Kartal, 2018). Domain kognitif meliputi pemikiran kritis, kreativitas, fungsi eksekutif, dan keterampilan pemecahan masalah (Silber- Varod et al., 2019; Araiza-Alba et al., 2021; Funke et al., 2018. Problem solving skills dibutuhkan untuk dikuasai mahasiswa terutama dalam perubahan masyarakat digital yang berubah dengan cepat.

Problem solving skills merupakan keterampilan yang harus dimiliki oleh setiap mahasiswa. Mahasiswa tentunya sering mengalami persoalan atau masalah baik yang terkait dengan masalah pribadi maupun masalah studinya. Seseorang yang mempunyai masalah akan berusaha mencari solusi untuk menyelesaikan masalah yang sedang dihadapinya. Dalam menyelesaikan dan menghadapinya dibutuhkan proses atau keterampilan berpikir yang berbeda-beda setiap individu. Problem solving skills merupakan bagian dari proses aktualisasi berpikir mahasiswa dalam menyelesaikan sebuah masalah yang akan diselesaikan.

Beberapa hasil penelitian membuktikan bahwa penguasaan problem solving skill berpengaruh terhadap kemampuan berfikir kritis (Wechsler et al., 2018; Changwong et al., 2018; Ulger, 2018), kemampuan berfikir kreatif (Kashani-Vahid et al., 2017; Tambunan, 2019; Puccio, 2017), motivasi belajar mahasiswa (Araiza-Alba et al., 2021; Georgiou \& Kyza, 2018, kecerdasan emosi (Drigas \& Papoutsi, 2018) serta juga keterampilan sosial mahasiswa (Stoeffler et al., 2020). Penelitian ini bertujuan untuk menganalisis tingkat Problem solving skills mahasiswa dan perbedaannya berdasarkan jenis kelamin,status perkembangan, dan usia.

\section{Method}

Metode penelitian dalam penelitian ini menggunakan metode kuantittaif deskriptif. sampel penelitian berjumlah 300 mahasiswa yang dipilih dengan teknik stratified random sampling. Instrument penelitian menggunakan skala problem solving skills mahasiswa yang terdiri dari 28 item pernyataan yang dikembangkan oleh peneliti dan telah melalui proses uji validitas dan reliabilitas dengan nilai koefisien realibilitas sebesar 0.896. Analisis data menggunakan analisis deskriptif, Uji independent sampel t test, dan ANOVA dengan bantuan program SPSS. 


\section{Results and Discussions}

Tingkat Problem Solving Skill Mahasiswa

Tabel $1<$ Tingkat Problem Solving Skill Mahasiswa $>$

\begin{tabular}{lccc}
\hline Kategori & Skor & Frekuensi & Persentase \\
Sangat rendah & $28-49$ & 0 & $0 \%$ \\
Rendah & $50-70$ & 7 & $2,3 \%$ \\
Sedang & $71-91$ & 187 & $62,3 \%$ \\
Tinggi & $92-112$ & 106 & $35,3 \%$ \\
& & 300 & $100 \%$ \\
\hline
\end{tabular}

Berdasarkan tabel 1 dapat digambarkan bahwa 2,3\% mahasiswa berada pada tingkat Problem Solving Skill rendah, 62,3\% mahasiswa berada pada tingkat Problem Solving Skill sedang, 35,3\% mahasiswa berada pada tingkat Problem Solving Skill tinggi dan tidak ada mahasiswa yang berada pada kategori tingkat Problem Solving Skill sangat rendah. Dapat disimpulkan bahwa mahasiswa yang mempunyai prosentase paling banyak adalah mahasiswa yang berada dalam kategori tingkat Problem Solving Skill sedang (62,3 \%).

\section{Problem Solving Skill Mahasiswa Berdasarkan Jenis Kelamin}

Tabel 2 <Perbedaan Tingkat Problem Solving Skill Mahasiswa Berdasarkan Jenis Kelamin>

\begin{tabular}{lcccc}
\hline Jenis_kelamin & N & Mean & Std. Deviation & Std. Error Mean \\
Laki-laki & 97 & 87.78 & 6.987 & .709 \\
Perempuan & 202 & 87.73 & 7.118 & .501 \\
\hline
\end{tabular}

Berdasarkan tabel 2 dapat diketahui jumlah data Problem Solving Skill untuk mahasiswa (laki-laki) sebanyak 97 mahasiswa, sementara jumlah data Problem Solving Skill untuk mahasiswi (perempuan) sebanyak 202 mahasiswa. Nilai rata-rata Problem Solving Skill untuk mahasiswa adalah sebesar 87,78, sementara nilai ratarata Problem Solving Skill untuk mahasiswi adalah sebesar 87,73. Dengan demikian secara deskriptif statistik dapat disimpulkan tidak ada perbedaan Problem Solving Skill antara mahasiswa dan mahasiswi.

Tabel 3 <Hasil Uji Independent Samples Test Problem Solving Skill Mahasiswa Berdasarkan Jenis Kelamin>

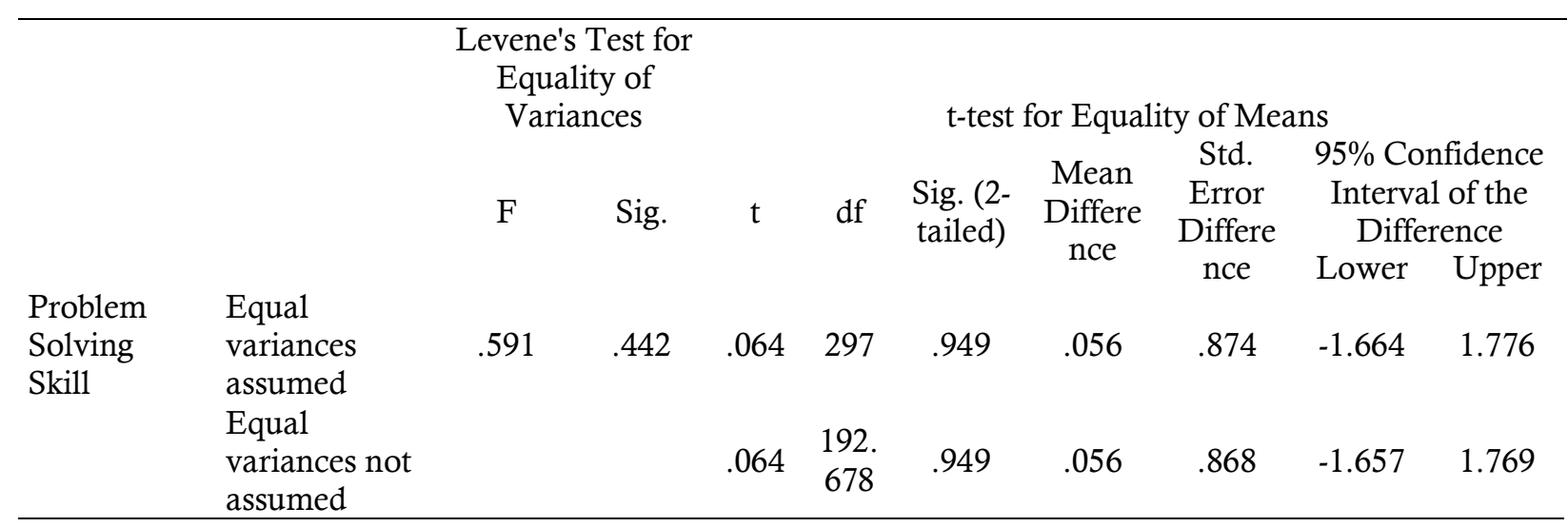

Berdasarkan tabel 3 diketahui nilai sig. Levene's Test for Equality of Variances adalah sebesar 0, 591 > 0,05 maka dapat diartikan bahwa varians data kelompok laki-laki dan kelompok perempuan adalah homogeny atau sama. Sehingga penafsiran table output samples test diatas berpedoman pada nilai yang terdapat dalam tabel Equal variances assumed.

Berdasarkan tabel 3 pada bagian Equal variances assumed diketahui nilai Sig.(2-tailed) sebesar 0,949 > 0,05, maka dapat disimpulkan H0 diterima dan Ha ditolak. Dengan demikian dapat disimpulkan bahwa tidak ada perbedaan yang signifikan tingkat problem solving skill antara mahasiswa dan mahasiswi atau tidak ada perbedaan yang signifikan tingkat problem solving skill mahasiswa berdasarkan jenis kelamin. Hal ini juga tampak dari nilai "mean difference" antar dua kelompok tersebut sebesar 0,056. Nilai ini menunjukkan selisih antara rata-rata skor problem solving skill antara mahasiswa dan mahasiswi relatif rendah. 


\section{Problem Solving Skill Mahasiswa Berdasarkan Berdasarkan Status Perkembangan}

Tabel $4<$ Perbedaan Tingkat Problem Solving Skill Mahasiswa Berdasarkan Berdasarkan Status Perkembangan

\begin{tabular}{llllcc}
\hline \multirow{3}{*}{ Skor } & Status perkembangan & $\mathbf{N}$ & Mean & Std. Deviation & Std. Error Mean \\
& Remaja akhir & 170 & 87.32 & 6.734 & .516 \\
& Dewasa Awal & 130 & 88.26 & 7.453 & .654 \\
\hline
\end{tabular}

Berdasarkan tabel 4 dapat diketahui jumlah data Problem Solving Skill untuk mahasiswa yang berada pada usia perkembangan remaja akhir sebanyak 170 mahasiswa, sementara jumlah data Problem Solving Skill untuk mahasiswa yang berada pada usia perkembangan dewasa awal sebanyak 130 mahasiswa. Nilai rata-rata Problem Solving Skill untuk mahasiswa yang berada pada usia perkembangan remaja akhir adalah sebesar 87,32, sementara nilai rata-rata Problem Solving Skill untuk mahasiswa yang berada pada usia perkembangan dewasa awal adalah sebesar 88,26 . Dengan demikian secara deskriptif statistik dapat disimpulkan ada perbedaan Problem Solving Skill antara mahasiswa yang berada pada usia perkembangan remaja akhir dan mahasiswa yang berada pada usia perkembangan dewasa awal.

Tabel $5<$ Hasil Uji Independent Samples Test Problem Solving Skill Mahasiswa Berdasarkan Berdasarkan Status

Perkembangan

\begin{tabular}{|c|c|c|c|c|c|c|c|c|c|}
\hline \multirow{4}{*}{$\begin{array}{l}\text { Equal variances } \\
\text { assumed } \\
\text { Equal variances }\end{array}$} & \multicolumn{4}{|c|}{$\begin{array}{l}\text { Levene's Test for } \\
\text { Equality of } \\
\text { Variances }\end{array}$} & \multicolumn{3}{|c|}{ t-test for Equality of Mean } & \multirow{2}{*}{\multicolumn{2}{|c|}{$\begin{array}{l}\text { 95\% Confidence } \\
\text { Interval of the } \\
\text { Difference }\end{array}$}} \\
\hline & & & & & Sig. (2- & $\begin{array}{l}\text { Mean } \\
\text { Differen }\end{array}$ & $\begin{array}{c}\text { Std. } \\
\text { Error } \\
\text { Differen }\end{array}$ & & \\
\hline & $\begin{array}{l}\mathrm{F} \\
.435\end{array}$ & $\begin{array}{l}\text { Sig. } \\
\quad .510\end{array}$ & $\begin{array}{c}\mathrm{t} \\
1.141\end{array}$ & $\begin{array}{l}\mathrm{df} \\
298\end{array}$ & $\begin{array}{l}\text { tailed) } \\
.255\end{array}$ & $\begin{array}{l}\text { ce } \\
-.938\end{array}$ & $\begin{array}{l}\mathrm{ce} \\
.822\end{array}$ & $\begin{array}{l}\text { Lower } \\
-2.555\end{array}$ & $\begin{array}{r}\text { Upper } \\
.679\end{array}$ \\
\hline & & & 1.126 & $\begin{array}{r}262.3 \\
08\end{array}$ & .261 & -.938 & .833 & -2.578 & .702 \\
\hline
\end{tabular}

Berdasarkan tabel 5 diketahui nilai sig. Levene's Test for Equality of Variances adalah sebesar 0, $510>0,05$ maka dapat diartikan bahwa varians data kelompok mahasiswa yang berada pada usia perkembangan remaja akhir dan mahasiswa yang berada pada usia perkembangan dewasa awal adalah homogeny atau sama. Sehingga penafsiran table output samples test diatas berpedoman pada nilai yang terdapat dalam tabel Equal variances assumed.

Berdasarkan tabel 5 pada bagian Equal variances assumed diketahui nilai Sig.(2-tailed) sebesar 0,255 > 0,05, maka dapat disimpulkan H0 diterima dan Ha ditolak. Dengan demikian dapat disimpulkan bahwa tidak ada perbedaan yang signifikan tingkat problem solving skill antara mahasiswa yang berada pada usia perkembangan remaja akhir dan mahasiswa yang berada pada usia perkembangan dewasa awal atau tidak ada perbedaan yang signifikan tingkat problem solving skill mahasiswa berdasarkan status perkembangan. Hal ini juga tampak dari nilai "mean difference" antar dua kelompok tersebut sebesar -0,938. Nilai ini menunjukkan selisih antara rata-rata skor problem solving skill antara mahasiswa yang berada pada usia perkembangan remaja akhir dan mahasiswa yang berada pada usia perkembangan dewasa awal relatif rendah.

Berdasarkan tabel 6, kita dapat melihat perbedaan rata-rata skor problem solving skill mahasiswa berdasarkan 5 kelompok usia dengan rincian sebagai berikut:

1. Rata-rata skor problem solving skill mahasiswa usia 19 tahun sebesar 88,23

2. Rata-rata skor problem solving skill mahasiswa usia 20 tahun sebesar 87,13

3. Rata-rata skor problem solving skill mahasiswa usia 21 tahun sebesar 87,64

4. Rata-rata skor problem solving skill mahasiswa usia 22 tahun sebesar 88,88

5. Rata-rata skor problem solving skill mahasiswa usia 23 tahun sebesar 95,60

Dengan demikian secara deskriptif dapat disimpulkan bahwa terdapat perbedaan rata-rata skor problem solving skill mahasiswa berdasarkan kelompok usia. Rata-rata skor problem solving skill mahasiswa yang paling tinggi yaitu berasal dari kelompok usia 23 tahun. 
Problem Solving Skill Mahasiswa Berdasarkan Berdasarkan Usia

Tabel $6<$ Perbedaan Tingkat Problem Solving Skill Mahasiswa Berdasarkan Usia

\begin{tabular}{|c|c|c|c|c|c|c|c|c|}
\hline & & & \multicolumn{6}{|c|}{$\begin{array}{l}\text { 95\% Confidence Interval } \\
\text { for Mean }\end{array}$} \\
\hline & & & Std. & Std. & Lower & Upper & & \\
\hline & $\mathrm{N}$ & Mean & Deviation & Error & Bound & Bound & Minimum & Maximum \\
\hline 19 tahun & 30 & 88.23 & 5.450 & .995 & 86.20 & 90.27 & 73 & 97 \\
\hline 20 tahun & 140 & 87.13 & 6.980 & .590 & 85.96 & 88.29 & 64 & 102 \\
\hline 21 tahun & 92 & 87.64 & 7.772 & .810 & 86.03 & 89.25 & 65 & 102 \\
\hline 22 tahun & 33 & 88.88 & 6.279 & 1.093 & 86.65 & 91.11 & 75 & 98 \\
\hline 23 tahun & 5 & 95.60 & 4.722 & 2.112 & 89.74 & 101.46 & 90 & 101 \\
\hline Total & 300 & 87.73 & 7.058 & .407 & 86.93 & 88.53 & 64 & 102 \\
\hline
\end{tabular}

Tabel $7<$ Hasil Test of Homogeneity of Variances

\begin{tabular}{|c|c|c|c|c|c|}
\hline \multirow{5}{*}{ Problem solving skill } & & Levene Statistic & df1 & df2 & Sig. \\
\hline & Based on Mean & 1.427 & 4 & 295 & .225 \\
\hline & Based on Median & 1.258 & 4 & 295 & .287 \\
\hline & $\begin{array}{l}\text { Based on Median and with } \\
\text { adjusted df }\end{array}$ & 1.258 & 4 & 261.422 & .287 \\
\hline & Based on trimmed mean & 1.291 & 4 & 295 & .274 \\
\hline
\end{tabular}

Berdasarkan tabel 7 diperoleh angka Levene Statistic Based on Mean dengan nilai signifikansi atau probabilitas (sig) sebesar 0,225. Karena nilai signifikansi 0,225 lebih besar dari 0,05, maka dapat disimpulkan bahwa varian 5 kelompok yang kita bandingkan adalah sama

Tabel $8<$ Hasil Analisis ANOVA Tentang Perbedaan Rata-Rata Kelima Kelompok Usia

\begin{tabular}{lccccc}
\hline & Sum of Squares & df & Mean Square & F & Sig. \\
Between Groups & 412.199 & 4 & 103.050 & 2.099 & .081 \\
Within Groups & 14480.931 & 295 & 49.088 & & \\
Total & 14893.130 & 299 & & \\
\hline
\end{tabular}

Berdasarkan tabel 8 diketahui nilai signifikansi sebesar 0,081 > 0,05 sehingga dapat disimpulkan bahwa rata-rata kelima kelompok sama.

Pada tabel 9 kita akan membandingkan rata-rata skor problem solving skill mahasiswa. Secara lengkap akan dijabarkan sebagai berikut:

1. Perbandingan rata-rata skor problem solving skill mahasiswa usia 19 tahun dan 20 tahun,tampak pada angka perbedaan kedua kelompok tersebut adalah 1,105. Perbedaan rata-rata skor problem solving skill mahasiswa kedua kelompok ini berkisar antara -2,76 (lower bound) sampai dengan 4,97 (upper bound) pada tingkat kepercayaan 95\%. Berdasarkan tabel tersebut juga dapat diketahui nilai Sig sebesar 0,935 $>0,05$, maka dapat disimpulkan bahwa rata-rata skor problem solving skill mahasiswa usia 19 tahun dan 20 tahun adalah sama.

2. Perbandingan rata-rata skor problem solving skill mahasiswa usia 19 tahun dan 21 tahun,tampak pada angka perbedaan kedua kelompok tersebut adalah 0,592. Perbedaan rata-rata skor problem solving skill mahasiswa kedua kelompok ini berkisar antara -3,45 (lower bound) sampai dengan 4,64 (upper bound) pada tingkat kepercayaan 95\%. Berdasarkan tabel tersebut juga dapat diketahui nilai Sig sebesar 0,994 $>$ 0,05, maka dapat disimpulkan bahwa rata-rata skor problem solving skill mahasiswa usia 19 tahun dan 21 tahun adalah sama.

3. Perbandingan rata-rata skor problem solving skill mahasiswa usia 19 tahun dan 22 tahun,tampak pada angka perbedaan kedua kelompok tersebut adalah -0,645. Perbedaan rata-rata skor problem solving skill mahasiswa kedua kelompok ini berkisar antara -5,50 (lower bound) sampai dengan 4,21 (upper bound) pada tingkat kepercayaan 95\%. Berdasarkan tabel tersebut juga dapat diketahui nilai Sig sebesar 0,996 $>0,05$, maka dapat disimpulkan bahwa rata-rata skor problem solving skill mahasiswa usia 19 tahun dan 22 tahun adalah sama. 
Tabel $9<$ Hasil Analisis Perbedaan Rata Skor Problem Solving Skill Mahasiswa Antar Kelompok Usia

Dependent Variable: problem solving skill

Tukey HSD

\begin{tabular}{|c|c|c|c|c|c|c|}
\hline \multirow[b]{2}{*}{ (I) usia } & \multirow{2}{*}{ (J) usia } & \multirow{2}{*}{$\begin{array}{c}\text { Mean Difference } \\
(\mathrm{I}-\mathrm{J})\end{array}$} & \multirow{2}{*}{ Std. Error } & \multirow{2}{*}{ Sig. } & \multicolumn{2}{|c|}{ 95\% Confidence Interval } \\
\hline & & & & & Lower Bound & Upper Bound \\
\hline \multirow[t]{4}{*}{19 tahun } & 20 tahun & 1.105 & 1.410 & .935 & -2.76 & 4.97 \\
\hline & 21 tahun & .592 & 1.473 & .994 & -3.45 & 4.64 \\
\hline & 22 tahun & -.645 & 1.767 & .996 & -5.50 & 4.21 \\
\hline & 23 tahun & -7.367 & 3.384 & .191 & -16.66 & 1.92 \\
\hline \multirow[t]{4}{*}{20 tahun } & 19 tahun & -1.105 & 1.410 & .935 & -4.97 & 2.76 \\
\hline & 21 tahun & -.513 & .940 & .982 & -3.09 & 2.07 \\
\hline & 22 tahun & -1.750 & 1.356 & .697 & -5.47 & 1.97 \\
\hline & 23 tahun & -8.471 & 3.189 & .063 & -17.22 & .28 \\
\hline \multirow[t]{4}{*}{21 tahun } & 19 tahun & -.592 & 1.473 & .994 & -4.64 & 3.45 \\
\hline & 20 tahun & .513 & .940 & .982 & -2.07 & 3.09 \\
\hline & 22 tahun & -1.237 & 1.422 & .908 & -5.14 & 2.66 \\
\hline & 23 tahun & -7.959 & 3.217 & .099 & -16.79 & .87 \\
\hline \multirow[t]{4}{*}{22 tahun } & 19 tahun & .645 & 1.767 & .996 & -4.21 & 5.50 \\
\hline & 20 tahun & 1.750 & 1.356 & .697 & -1.97 & 5.47 \\
\hline & 21 tahun & 1.237 & 1.422 & .908 & -2.66 & 5.14 \\
\hline & 23 tahun & -6.721 & 3.362 & .269 & -15.95 & 2.51 \\
\hline \multirow[t]{4}{*}{23 tahun } & 19 tahun & 7.367 & 3.384 & .191 & -1.92 & 16.66 \\
\hline & 20 tahun & 8.471 & 3.189 & .063 & -.28 & 17.22 \\
\hline & 21 tahun & 7.959 & 3.217 & .099 & -.87 & 16.79 \\
\hline & 22 tahun & 6.721 & 3.362 & .269 & -2.51 & 15.95 \\
\hline
\end{tabular}

Pada tabel 9 kita akan membandingkan rata-rata skor problem solving skill mahasiswa. Secara lengkap akan dijabarkan sebagai berikut (sambungan):

4. Perbandingan rata-rata skor problem solving skill mahasiswa usia 19 tahun dan 23 tahun,tampak pada angka perbedaan kedua kelompok tersebut adalah -7,367. Perbedaan rata-rata skor problem solving skill mahasiswa kedua kelompok ini berkisar antara -16,66 (lower bound) sampai dengan 1,92 (upper bound) pada tingkat kepercayaan 95\%. Berdasarkan tabel tersebut juga dapat diketahui nilai Sig sebesar 0,191 $>0,05$, maka dapat disimpulkan bahwa rata-rata skor problem solving skill mahasiswa usia 19 tahun dan 23 tahun adalah sama.

5. Perbandingan rata-rata skor problem solving skill mahasiswa usia 20 tahun dan 21 tahun,tampak pada angka perbedaan kedua kelompok tersebut adalah -0,513. Perbedaan rata-rata skor problem solving skill mahasiswa kedua kelompok ini berkisar antara -3,09 (lower bound) sampai dengan 2,07 (upper bound) pada tingkat kepercayaan 95\%. Berdasarkan tabel tersebut juga dapat diketahui nilai Sig sebesar 0,982 $>0,05$, maka dapat disimpulkan bahwa rata-rata skor problem solving skill mahasiswa usia 20 tahun dan 21 tahun adalah sama.

6. Perbandingan rata-rata skor problem solving skill mahasiswa usia 20 tahun dan 22 tahun,tampak pada angka perbedaan kedua kelompok tersebut adalah -1,750. Perbedaan rata-rata skor problem solving skill mahasiswa kedua kelompok ini berkisar antara -5,47 (lower bound) sampai dengan 1,97 (upper bound) pada tingkat kepercayaan 95\%. Berdasarkan tabel tersebut juga dapat diketahui nilai Sig sebesar 0,697 $>0,05$, maka dapat disimpulkan bahwa rata-rata skor problem solving skill mahasiswa usia 20 tahun dan 22 tahun adalah sama.

7. Perbandingan rata-rata skor problem solving skill mahasiswa usia 20 tahun dan 23 tahun,tampak pada angka perbedaan kedua kelompok tersebut adalah -8,471. Perbedaan rata-rata skor problem solving skill mahasiswa kedua kelompok ini berkisar antara -17,22 (lower bound) sampai dengan 0,28 (upper bound) pada tingkat kepercayaan 95\%. Berdasarkan tabel tersebut juga dapat diketahui nilai Sig sebesar 0,063 $>0,05$, maka dapat disimpulkan bahwa rata-rata skor problem solving skill mahasiswa usia 20 tahun dan 23 tahun adalah sama.

8. Perbandingan rata-rata skor problem solving skill mahasiswa usia 21 tahun dan 22 tahun,tampak pada angka perbedaan kedua kelompok tersebut adalah -1,237. Perbedaan rata-rata skor problem solving skill mahasiswa kedua kelompok ini berkisar antara -5,14 (lower bound) sampai dengan 2,66 (upper bound) pada tingkat kepercayaan 95\%. Berdasarkan tabel tersebut juga dapat diketahui nilai Sig sebesar 0,908 
$>0,05$, maka dapat disimpulkan bahwa rata-rata skor problem solving skill mahasiswa usia 21 tahun dan 22 tahun adalah sama.

9. Perbandingan rata-rata skor problem solving skill mahasiswa usia 21 tahun dan 23 tahun,tampak pada angka perbedaan kedua kelompok tersebut adalah -7,959. Perbedaan rata-rata skor problem solving skill mahasiswa kedua kelompok ini berkisar antara -16,79 (lower bound) sampai dengan 0,87 (upper bound) pada tingkat kepercayaan 95\%. Berdasarkan tabel tersebut juga dapat diketahui nilai Sig sebesar 0,099 $>0,05$, maka dapat disimpulkan bahwa rata-rata skor problem solving skill mahasiswa usia 21 tahun dan 23 tahun adalah sama.

10. Perbandingan rata-rata skor problem solving skill mahasiswa usia 22 tahun dan 23 tahun,tampak pada angka perbedaan kedua kelompok tersebut adalah -6.721. Perbedaan rata-rata skor problem solving skill mahasiswa kedua kelompok ini berkisar antara -15,95 (lower bound) sampai dengan 2,51 (upper bound) pada tingkat kepercayaan 95\%. Berdasarkan tabel tersebut juga dapat diketahui nilai Sig sebesar 0,269 $>0,05$, maka dapat disimpulkan bahwa rata-rata skor problem solving skill mahasiswa usia 21 tahun dan 23 tahun adalah sama.

Tabel $10<$ Hasil Analisis Kesamaan Rata-Rata Skor Problem Solving Skill Kelima Kelompok Usia

Tukey HSD ${ }^{\mathrm{a}, \mathrm{b}}$

\section{Problem Solving Skill}

\begin{tabular}{|c|c|c|c|c|}
\hline & & Subset for a & & \\
\hline Usia & $\mathrm{N}$ & 1 & 2 & \\
\hline 20 tahun & 140 & 87.13 & & \\
\hline 21 tahun & 92 & 87.64 & & \\
\hline 19 tahun & 30 & 88.23 & & \\
\hline 22 tahun & 33 & 88.88 & & \\
\hline 23 tahun & 5 & & & 95.60 \\
\hline Sig. & & .946 & & 1.000 \\
\hline
\end{tabular}

Means for groups in homogeneous subsets are displayed.

a. Uses Harmonic Mean Sample Size $=17.753$.

b. The group sizes are unequal. The harmonic mean of the group sizes is used. Type I error levels are not guaranteed.

Selanjutnya kita akan melihat kelompok mana saja yang memiliki perbadaan rata-rata secara signifikan. Berdasarkan tabel 10 dapat diketahui

1. Pada subset 1 terdapat data rata-rata skor problem solving skill mahasiswa usia 19, 20,21,22 tahun. Artinya rata-rata skor problem solving skill mahasiswa 4 kelompok usia tersebut tidak memiliki perbedaan yang signifikan. Dengan kata lain, rata-rata skor problem solving skill mahasiswa usia tersebut sama.

2. Pada subset 2 terdapat data rata-rata skor problem solving skill mahasiswa usia 23 tahun. Artinya rata-rata skor problem solving skill mahasiswa usia 23 tahun berbeda dengan rata-rata skor problem solving skill mahasiswa usia 19, 20,21,22.tahun.

Berdasarkan hasil analysis ini dapat diketahui hanya rata-rata skor problem solving skill mahasiswa usia 23 tahun yang berbeda, sedangkan rata-rata skor problem solving skill mahasiswa usia 19, 20,21,22.tahun adalah sama. Dengan demikian, variable usia hanya berpengaruh secara signifikan terhadap perbedaan rata-rata skor problem solving skill mahasiswa usia 23 tahun.

Problem solving skill merupakan salah satu keterampilan berpikir tingkat tinggi (higher order thinking skills) yang harus dibekalkan perguruan tinggi kepada mahasiswanya (Virtanen \& Tynjälä, 2019; Sulaiman et al., 2017; Husamah et al., 2018. Keterampilan ini sangat penting karena pada abad 21 mahasiswa hidup dalam dunia yang semakin kompleks dengan dengan segala tantangan dan beragam situasi kerja yang akan dihadapi nantinya. Hasil penelitian ini menunjukkan bahwa rata-rata mahasiswa berada dalam kategori tingkat problem solving skill sedang (62,3 \%). Hasil penelitian ini tentunya tidak sesuai dengan bebrapa hasil penelitian terdahulu yang menyatakan bahwa tingkat problem solving skill mahasiswa masih relatif rendah (Dörner \& Funke, 2017); Shishigu et al., 2017; Reddy \& Panacharoensawad, 2017).

Meskipun hasil penelitian ini menunjukkan bahwa rata-rata tingkat problem solving skill mahasiswa berada pada kategori sedang, perguruan tinggi tetap perlu merancang kegiatan yang dapat membantu meningkatkan problem solving skill menjadi tinggi. The National Association of Colleges and Employers(NACE) mengungkapkan soft skills teratas yang dibutuhkan dunia kerja adalah kemampuan pemecahan masalah (Martin, 2019; (Gale et al., 2017). Selain itu Peng \& Luo (2021) menjelaskan bahwa setiap perguruan tinggi pasti ingin setiap 
lulusannya tidak hanya menjadi ahli dalam bidang tertentu tetapi juga memiliki kepribadian yang matang yang siap bersaing di dunia kerja.

Problem solving skill merupakan keterampilan kognitif yang bersifat kompleks yang dapat dikatakan sebagai kemampuan paling cerdas yang dimiliki manusia (Kraft, 2019). Dalam memecahkan masalah yang dihadapi, seorang individu tidak hanya sekedar perlu berfikir tapi juga perlu berfikir kreatif untuk dapat menyelesaikan masalah tersebut. Individu akan melakukan langkah-langkah yang terkait dengan proses kognitif agar masalah yang dihadapi dapat terselesaikan dengan baik.

Mengingat problem solving skill merupakan salah satu keterampilan berpikir tingkat tinggi (higher order thinking skills) yang berifat kompleks, maka kemampuan menyelesaikan masalah pada setiap individu pasti berbeda. Ada sebagian individu yang tidak kesulitan dalam menyelesaikan masalah, namun ada juga sebagian individu yang kurang mampu dalam menyelesaikan masalah. Ada beberapa faktor yang mempengaruhi problem solving skill salah satunya jenis kelamin. Menurut Putri \& Alfani (2021) laki-laki lebih bisa memahami masalah dan melaksanakan pemecahan masalah dibandingkan perempuan. Mefoh et al.,( 2017) dalam hasil penelitiannya juga menyatakan remaja laki-laki mengungguli remaja perempuan dalam tugas pemecahan masalah.

Hasil penelitian tersebut berbeda dengan hasil penelitian ini, yang membuktikan bahwa tidak ada perbedaan yang signifikan tingkat problem solving skill mahasiswa berdasarkan jenis kelamin. Rata-rata skor problem solving skill mahasiswa antara laki-laki dan perempuan adalah sama. Miner et al., (2018) menyatakan tingkat problem solving skill tidak selalu bergantung pada kecerdasan dan jenis kelamin tetapi kepada pengalaman individu. Pengalaman terhadap tugas-tugas maupun pengalaman langsung dalam mengatasi sebuah masalah mampu mempermudah seseorang dalam menguasai problem solving skill.

Faktor selanjutnya yang menjadi temuan dalam penelitian ini adalah tidak ada perbedaan yang signifikan tingkat problem solving skill antara mahasiswa yang berada pada usia perkembangan remaja akhir dan mahasiswa yang berada pada usia perkembangan dewasa awal atau tidak ada perbedaan yang signifikan tingkat problem solving skill mahasiswa berdasarkan status perkembangan. Mahasiswa yang rata-rata berada pada akhir masa remaja dan awal masa dewasa mengalami perubahan yang cepat dalam aspek biologi, intelektual, emosional, nilai dan sikap menuju kearah kematangan dan kemantapan kepribadian. Berbagai persoalan mereka hadapi sehingga mengasah problem solving skill yang dimiliki (Wijaya, 2021).

Meskipun secara status perkembangan ditemukan tidak ada perbedaan yang signifikan tingkat problem solving skill mahasiswa, namun berdasarkan kelompok usia, ditemukan perbedaan rata-rata skor problem solving skill yang dikuasai mahasiswa. Berdasarkan hasil analisis hanya rata-rata skor problem solving skill mahasiswa usia 23 tahun yang berbeda, sedangkan rata-rata skor problem solving skill mahasiswa usia 19, 20,21,22 tahun adalah sama. Dengan demikian,kelompok usia hanya berpengaruh secara signifikan terhadap perbedaan ratarata skor problem solving skill mahasiswa usia 23 tahun. Semakin bertambah usia maka individu akan menjadi pribadi yang semakin matang dan kemampuan pemecahan masalah akan semakin bertambah (Chen et al., 2017). Kematangan tersebut ditunjukkan dengan usaha pemecahan masalah yang merupakan produk dari kemampuan berpikir yang lebih sempurna yang ditunjang dengan sikap serta pandangan yang rasional.

\section{Conclusions}

Berdasarkan hasil penelitian dapat disimpulkan (1) rata-rata tingkat problem solving skill mahasiswa berada pada kategori sedang $(62,3 \%)$, (2) tidak ada perbedaan yang signifikan tingkat problem solving skill mahasiswa berdasarkan jenis kelamin, (3) tidak ada perbedaan yang signifikan tingkat problem solving skill mahasiswa berdasarkan status perkembangan, (4) ada perbedaan yang signifikan tingkat problem solving skill mahasiswa berdasarkan kelompok usia. Kelompok usia yang berpengaruh secara signifikan terhadap perbedaan rata-rata skor problem solving skill mahasiswa usia 23 tahun.

\section{References}

Akben, N. (2020). Effects of the problem-posing approach on students' problem solving skills and metacognitive awareness in science education. Research in Science Education, 50(3), 1143-1165.

Araiza-Alba, P., Keane, T., Chen, W. S., \& Kaufman, J. (2021). Immersive virtual reality as a tool to learn problem-solving skills. Computers \& Education, 164, 104121.

Arifin, S., \& Muslim, M. (2020). Tantangan Implementasi Kebijakan "Merdeka Belajar, Kampus Merdeka" pada Perguruan Tinggi Islam Swasta di Indonesia. Jurnal Pendidikan Islam Al-Ilmi, 3(1).

Care, E., Kim, H., Vista, A., \& Anderson, K. (2018). Education System Alignment for 21st Century Skills: 
Focus on Assessment. Center for Universal Education at The Brookings Institution.

Chalkiadaki, A. (2018). A systematic literature review of 21st century skills and competencies in primary education. International Journal of Instruction, 11(3), 1-16.

Changwong, K., Sukkamart, A., \& Sisan, B. (2018). Critical thinking skill development: Analysis of a new learning management model for Thai high schools. Journal of International Studies, 11(2).

Chen, X., Hertzog, C., \& Park, D. C. (2017). Cognitive predictors of everyday problem solving across the lifespan. Gerontology, 63(4), 372-384.

Cheng, K. (2017). Advancing 21st century competencies in East Asian education systems. Center for Global Education. Asia Society, 2, 26.

Dörner, D., \& Funke, J. (2017). Complex problem solving: what it is and what it is not. Frontiers in Psychology, 8, 1153.

Drigas, A. S., \& Papoutsi, C. (2018). A new layered model on emotional intelligence. Behavioral Sciences, 8(5), 45.

Funke, J., Fischer, A., \& Holt, D. V. (2018). Competencies for complexity: problem solving in the twenty-first century. In Assessment and teaching of 21st century skills (pp. 41-53). Springer.

Gale, A. J., Duffey, M. A., Park- Gates, S., \& Peek, P. F. (2017). Soft Skills versus hard skills: practitioners' perspectives on interior design interns. Journal of Interior Design, 42(4), 45-63.

Georgiou, Y., \& Kyza, E. A. (2018). Relations between student motivation, immersion and learning outcomes in location-based augmented reality settings. Computers in Human Behavior, 89, 173-181.

Graesser, A. C., Fiore, S. M., Greiff, S., Andrews-Todd, J., Foltz, P. W., \& Hesse, F. W. (2018). Advancing the science of collaborative problem solving. Psychological Science in the Public Interest, 19(2), 59-92.

Husamah, H., Fatmawati, D., \& Setyawan, D. (2018). OIDDE learning model: Improving higher order thinking skills of biology teacher candidates. International Journal of Instruction, 11(2), 249-264.

Ichsan, I. Z., Sigit, D. V., Miarsyah, M., Ali, A., Arif, W. P., \& Prayitno, T. A. (2019). HOTS-AEP: Higher Order Thinking Skills from Elementary to Master Students in Environmental Learning. European Journal of Educational Research, 8(4), 935-942.

Johnson, B. T., \& Acabchuk, R. L. (2018). What are the keys to a longer, happier life? Answers from five decades of health psychology research. Social Science \& Medicine, 196, 218-226.

Kashani-Vahid, L., Afrooz, G., Shokoohi-Yekta, M., Kharrazi, K., \& Ghobari, B. (2017). Can a creative interpersonal problem solving program improve creative thinking in gifted elementary students? Thinking Skills and Creativity, 24, 175-185.

Kraft, M. A. (2019). Teacher effects on complex cognitive skills and social-emotional competencies. Journal of Human Resources, 54(1), 1-36.

Kutlu, Ö., \& Kartal, S. K. (2018). The Prominent Student Competences of the 21st Century Education and the Transformation of Classroom Assessment. International Journal of Progressive Education, 14(6), 70-82.

Martin, T. (2019). Review of student soft skills development using the 5Ws/H approach resulting in a realistic, experiential, applied, active learning and teaching pedagogical classroom. Journal of Behavioral and Applied Management, 19(1), 41-57.

Mefoh, P. C., Nwoke, M. B., Chukwuorji, J. C., \& Chijioke, A. O. (2017). Effect of cognitive style and gender on adolescents' problem solving ability. Thinking Skills and Creativity, 25, 47-52.

Mestry, R. (2017). Empowering principals to lead and manage public schools effectively in the 21 st century. South African Journal of Education, 37(1).

Meyer, M. W., \& Norman, D. (2020). Changing Design Education for the 21st Century. She Ji: The Journal of Design, Economics, and Innovation, 6(1), 13-49.

Miner, K. N., Walker, J. M., Bergman, M. E., Jean, V. A., Carter-Sowell, A., January, S. C., \& Kaunas, C. (2018). From "her" problem to "our" problem: Using an individual lens versus a social-structural lens to understand gender inequity in STEM. Industrial and Organizational Psychology, 11(2), 267-290.

Özreçberoğlu, N., \& Çağanağa, Ç. K. (2018). Making it count: Strategies for improving problem-solving skills in mathematics for students and teachers' classroom management. Eurasia Journal of Mathematics, Science and Technology Education, 14(4), 1253-1261.

Peng, L., \& Luo, S. (2021). Impact of social economic development on personality traits among Chinese college students: A cross-temporal meta-analysis, 2001-2016. Personality and Individual Differences, 171, 110461.

Pinter, R., \& Cisar, S. M. (2018). Measuring Team Member Performance in Project Based Learning. Journal of Applied Technical and Educational Sciences, 8(4), 22-34.

Puccio, G. J. (2017). From the dawn of humanity to the 21st century: Creativity as an enduring survival skill. The Journal of Creative Behavior, 51(4), 330-334.

Putri, O. R. U., \& Alfani, I. (2021). Mathematics Connection Process of Students With Low Mathematical Ability in Solving Contextual Problems Based on Gender. 4th Sriwijaya University Learning and Education 
International Conference (SULE-IC 2020), 549-555.

Reddy, M., \& Panacharoensawad, B. (2017). Students Problem-Solving Difficulties and Implications in Physics: An Empirical Study on Influencing Factors. Journal of Education and Practice, 8(14), 59-62.

Rios, J. A., Ling, G., Pugh, R., Becker, D., \& Bacall, A. (2020). Identifying critical 21st-century skills for workplace success: A content analysis of job advertisements. Educational Researcher, 49(2), 80-89.

Scoular, C., \& Care, E. (2018). Teaching Twenty-First Century Skills: Implications at System Levels in Australia. In Assessment and Teaching of 21st Century Skills (pp. 145-162). Springer.

Shishigu, A., Hailu, A., \& Anibo, Z. (2017). Problem-based learning and conceptual understanding of college female students in physics. Eurasia Journal of Mathematics, Science and Technology Education, 14(1), 145154.

Silber- Varod, V., Eshet- Alkalai, Y., \& Geri, N. (2019). Tracing research trends of 21st- century learning skills. British Journal of Educational Technology, 50(6), 3099-3118.

Stoeffler, K., Rosen, Y., Bolsinova, M., \& von Davier, A. A. (2020). Gamified performance assessment of collaborative problem solving skills. Computers in Human Behavior, 104, 106036.

Sulaiman, T., Muniyan, V., Madhvan, D., Hasan, R., \& Rahim, S. S. A. (2017). Implementation of higher order thinking skills in teaching of science: A case study in Malaysia. International Research Journal of Education and Sciences (IRJES), 1(1), 2158-2550.

Tambunan, H. (2019). The Effectiveness of the Problem Solving Strategy and the Scientific Approach to Students' Mathematical Capabilities in High Order Thinking Skills. International Electronic Journal of Mathematics Education, 14(2), 293-302.

Ulger, K. (2018). The effect of problem-based learning on the creative thinking and critical thinking disposition of students in visual arts education. Interdisciplinary Journal of Problem-Based Learning, 12(1), 10.

Urbani, J. M., Roshandel, S., Michaels, R., \& Truesdell, E. (2017). Developing and modeling 21st-century skills with preservice teachers. Teacher Education Quarterly, 44(4), 27-50.

Virtanen, A., \& Tynjälä, P. (2019). Factors explaining the learning of generic skills: a study of university students' experiences. Teaching in Higher Education, 24(7), 880-894.

Wechsler, S. M., Saiz, C., Rivas, S. F., Vendramini, C. M. M., Almeida, L. S., Mundim, M. C., \& Franco, A. (2018). Creative and critical thinking: Independent or overlapping components? Thinking Skills and Creativity, 27, 114-122.

Wijaya, T. T. (2021). How chinese students learn mathematics during the coronavirus pandemic. IJERI: International Journal of Educational Research and Innovation, 15, 1-16. 